\title{
A new species of flea-toad, genus Brachycephalus Fitzinger (Amphibia: Anura: Brachycephalidae), from the Atlantic rainforest of southern Bahia, Brazil
}

\author{
MARCELO FELGUEIRAS NAPOLI ${ }^{1,4,5}$, ULISSES CARAMASCHI ${ }^{2}$, \\ CARLOS ALBERTO GONÇALVES CRUZ ${ }^{2} \&$ IURI RIBEIRO DIAS ${ }^{3}$ \\ ${ }^{\prime}$ Universidade Federal da Bahia, Instituto de Biologia, Departamento de Zoologia, Museu de Zoologia, Rua Barão de Jeremoabo, \\ Campus Universitário de Ondina, 40170-115 Salvador, Bahia, Brazil \\ ${ }^{2}$ Universidade Federal do Rio de Janeiro, Museu Nacional, Departamento de Vertebrados, Quinta da Boa Vista, São Cristóvão, \\ 20940-040 Rio de Janeiro, Rio de Janeiro, Brazil \\ ${ }^{3}$ Universidade Estadual de Santa Cruz, Rodovia Ilhéus-Itabuna, km 16, 45662-900 Ilhéus, Bahia, Brazil \\ ${ }^{4}$ Associate Researcher, Departamento de Vertebrados, Museu Nacional/UFRJ \\ ${ }^{5}$ Corresponding author.E-mail: napoli@ufba.br
}

\begin{abstract}
We describe a new species of flea-toad related to Brachycephalus didactylus and B. hermogenesi from the Serra Bonita mountain, an Atlantic rainforest remnant in the Municipality of Camacan, State of Bahia, northeastern Brazil, constituting the northernmost record of the genus. Brachycephalus pulex sp. nov. is mainly diagnosed by the toe II externally absent, the toe V vestigial, fingers I and IV externally absent, and an inverted depigmented v-shaped mark on chest bordered above by a dark brown stripe on each side.
\end{abstract}

Key words: Brachycephalus pulex sp. nov., B. didactylus, B. hermogenesi, Psyllophryne

\section{Resumo}

Descrevemos uma nova espécie de sapo-pulga relacionada a Brachycephalus didactylus e B. hermogenesi proveniente da Serra Bonita, um remanescente de Floresta Atlântica no Município de Camacan, Estado da Bahia, nordeste do Brasil, constituindo o registro mais setentrional para o gênero. Brachycephalus pulex sp. nov. é principalmente diagnosticado pelo artelho II externamente ausente, artelho V vestigial, ausência externa dos dedos I e IV e uma marca em forma de v invertido sobre o peito, marginada superiormente por uma faixa marrom escura de cada lado.

\section{Introduction}

The Neotropical family Brachycephalidae Günther is currently composed by two genera, Brachycephalus Fitzinger and Ischnocnema Reinhardt and Lütken (Hedges et al. 2008; Frost 2010). The genus Brachycephalus comprises species that were until recently allocated in two genera, Brachycephalus and Psyllophryne Izecksohn (flea-toads), diagnosed from each other by the presence of an omosternum in the latter and by its absence in the former. Moreover, the combination of the usual vivid yellow to orange color of dorsal surfaces, larger body sizes (snout-vent length 9.3-19.7 mm), body bufoniform, and the inability to jump large distances prompt diagnose the species of the genus Brachycephalus from that included in Psyllophryne (with dorsal surfaces brown, tiny body sizes [snout-vent length 8.6-10.2 mm], body leptodactyliform, and long-distance jumpers). Nevertheless, a reduced omosternum in Brachycephalus ephippium Spix led Kaplan (2002) to consider the genus Psyllophryne a junior synonym of Brachycephalus.

In the current concept, the species of the genus Brachycephalus are leaf litter inhabitants, have small body sizes (snout-vent length 8.6-19.7 mm), phalangeal loss, and reduced number of toes (Alves et al. 2009). This 
genus currently comprises 16 species endemic to the Atlantic Rainforest of southern and southeastern Brazil (Haddad et al. 2010): B. alipioi Pombal and Gasparini; B. atelopoide Miranda-Ribeiro; B. brunneus Ribeiro, Alves, Haddad and Reis; B. bufonoides Miranda-Ribeiro; B. didactylus (Izecksohn); B. ephippium; B. ferruginus Alves, Ribeiro, Haddad and Reis; B. garbeana Miranda-Ribeiro; B. hermogenesi (Giaretta and Sawaya); B. izecksohni Ribeiro, Alves, Haddad and Reis; B. nodoterga Miranda-Ribeiro; B. pernix Pombal, Wistuba and Bornschein; $B$. pitanga Alves, Sawaya, Reis and Haddad; B. pombali Alves, Ribeiro, Haddad and Reis; B. toby Haddad, Alves, Clemente-Carvalho and Reis; and B. vertebralis Pombal. Out of these 16 species, only two are recognized as fleatoads, B. didactylus and B. hermogenesi.

Recent surveys of anurans in the Serra Bonita mountain, an Atlantic rainforest remnant in the Municipality of Camacan, State of Bahia, northeastern Brazil, led us to find an undescribed species of flea-toad allied to Brachycephalus didactylus and $B$. hermogenesi, which is described herein.

\section{Material and methods}

Specimens used for description or examined for comparisons are deposited in the following Brazilian collections: MNRJ (Museu Nacional, Rio de Janeiro), MZUESC (Museu de Zoologia, Universidade Estadual de Santa Cruz, Ilhéus, Bahia), and UFBA (Museu de Zoologia, Universidade Federal da Bahia, Salvador, Bahia).

Twelve measurements of specimens were used in the account, and are in millimeters. Ten measurements follow Napoli (2005): SVL (snout-vent length), ED (eye diameter), END (eye-nostril distance), UEW (upper eyelid width), IOD (interorbital distance), IND (internarial distance), NSD (nostril to tip of snout distance), THL (thigh length), TL (tibia length), and FL (foot length). The two other remaining measurements are: HL (head length: the perpendicular distance from the posterior margin of the head to the tip of snout), and HW (head width: the largest width of the head). Measurements were taken with the help of an ocular micrometer in an Olympus SZ51 stereomicroscope. Drawings were made using a Leica MZ6 stereomicroscope with a drawing tube.

We were unable to determine the sex of the specimens of the new species by the absence of external secondary sexual characters, noticeable vocal sacs or vocal slits, and because we decided to not use invasive procedures to avoid injuries to the preserved specimens of the type-series.

\section{Description of new species}

\section{Brachycephalus pulex sp. nov.}

Figures 1-3

Holotype. MNRJ 69646 (ex-UESC 8357), adult specimen, collected at the Serra Bonita mountain (15'23'S, 39³3'W, 830 m above sea level), Municipality of Camacan, State of Bahia, Brazil, on 04 July 2010, by I.R. Dias.

Paratopotypes. MZUESC 8352, adult specimen, collected on 25 March 2010, by I.R. Dias. MZUESC 86048605, adult specimens, collected on 26 July 2010, by I.R. Dias. UFBA 10415-10416, juveniles, collected on 16 April 2009, by M.F Napoli and A.Y.C. Vargas. UFBA 10455, sub-adult, collected on 11 September 2010, by I.R. Dias.

Diagnosis. The new species is promptly included in the genus Brachycephalus by the small body size (snoutvent length less than $18 \mathrm{~mm}$ ), reduced number of toes, terminal digits not expanded, toes without circumferential grooves, and digits apically pointed. Brachycephalus pulex is diagnosed from all its congeners by the combination of the following character states: (1) toe II externally absent; (2) toe V vestigial; (3) fingers I and IV externally absent; (4) body leptodactyliform; (5) small body size (adult specimens SVL 8.0-8.4 mm); (6) dorsal ground color maculated with variegated browns without yellow or orange vivid colors; (7) dorsum with a X-shaped mark from posterior corners of eyes to sacral region; (8) an inverted depigmented v-shaped mark on chest, bordered above by a dark brown stripe on each side; (9) smooth skin texture with no dermal co-ossification on top of the head and central part of the back body.

Comparisons with other species. Brachycephalus pulex is closely allied to B. didactylus and B. hermogenesi by the small body size (combined SVL of B. didactylus and B. hermogenesi 8.6-10.2 mm; B. pulex 8.0-8.4 mm), 
body leptodactyliform, dorsal ground color maculated with variegated browns without yellow or orange vivid colors, a dark brown $\mathrm{x}$-shaped mark on dorsum, and short and pointed snout with a rounded tip in dorsal view. These features promptly diagnose $B$. pulex from B. alipioi, B. atelopoide, B. brunneus, B. bufonoides, B. ephippium, $B$. ferruginus, B. garbeana, B. izecksohni, B. nodoterga, B. pernix, B. pitanga, B. pombali, and B. vertebralis, which have body size larger (combined SVL $9.3-19.7 \mathrm{~mm}$ ), body bufoniform, general body color vivid yellow to orange in life and pale cream in preservative (dorsal background color in B. brunneus brown, but not variegated), and rounded or mucronate snout shape in dorsal view. Brachycephalus pulex has smooth skin texture with no dermal co-ossification on top of the head and central part of the back body, whereas B. ephippium, B. nodoterga, and B. vertebralis have such characters. The toe II externally absent diagnoses $B$. pulex from all congeners, in which toe II is developed. Also, an only vestigial toe $\mathrm{V}$ diagnoses $B$. pulex from $B$. hermogenesi, which presents a small, but developed, toe V. The external absence of fingers I and IV diagnoses B. pulex from B. didactylus and $B$. hermogenesi, in which such fingers are vestigial. An inverted depigmented v-shaped mark on chest bordered above by a dark brown stripe on each side diagnoses $B$. pulex from $B$. didactylus, which has a dark brown trapezoidal mark on chest, and from $B$. hermogenesi (without dark brown marks on chest).

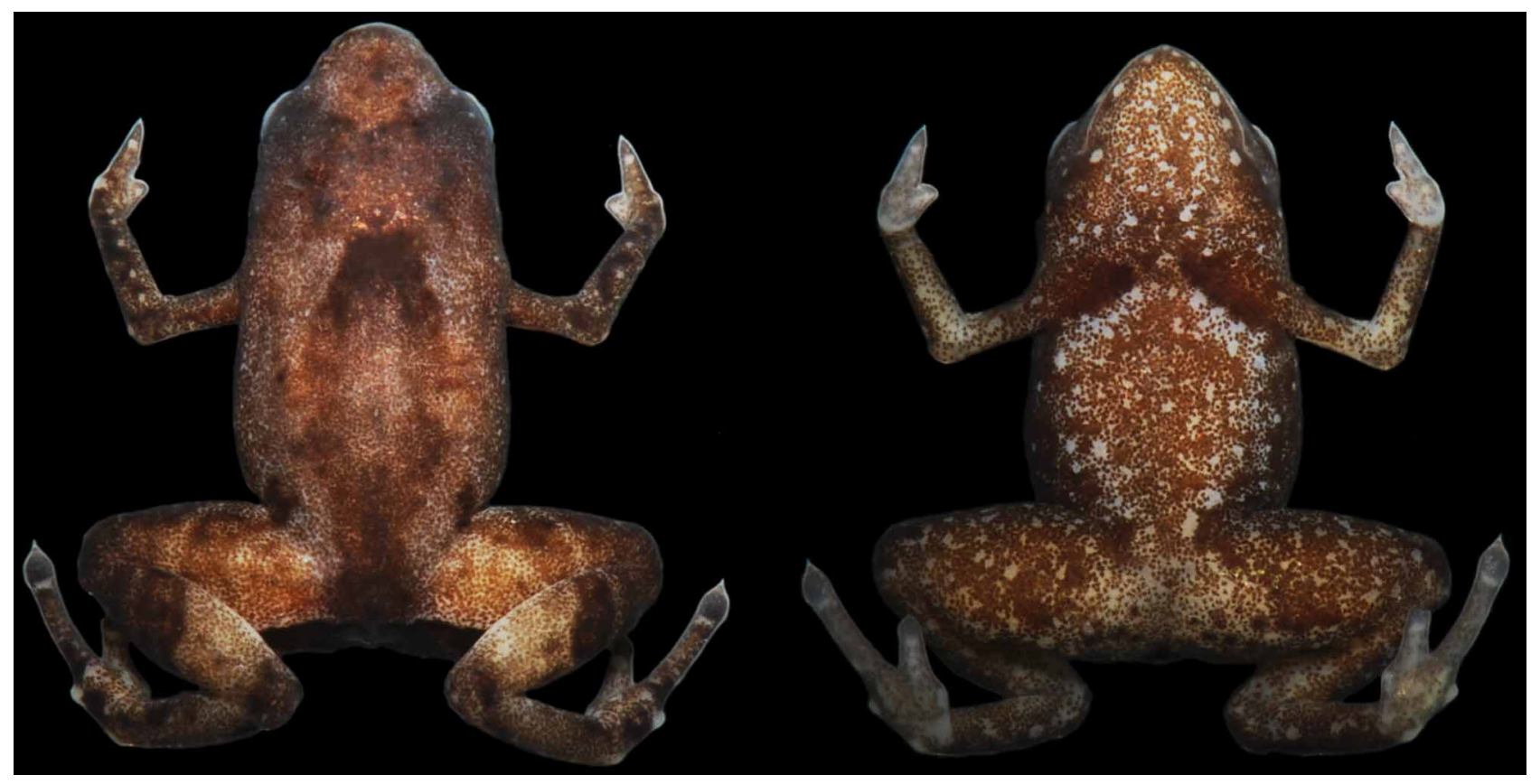

FIGURE 1. Brachycephalus pulex sp. nov. Dorsal and ventral views of the holotype, MNRJ 69646, adult specimen, SVL 8.2 mm. Photo Rafael O. Abreu.

Description of holotype. Body slender, leptodactyliform (Fig. 1). Head wider than long, its length $38 \%$ of snout-vent length; snout long with length almost equal to eye diameter, rounded in lateral and dorsal views (Fig. 2 A-B); nostrils directed anterolateraly, elliptical, elongated, almost perpendicular to the canthus rostralis; canthus rostralis rounded; loreal region weakly concave; lips nearly sigmoid; eye slightly protruding in dorsal and lateral views, eye diameter $42 \%$ of head length; tympanum indistinct; vocal sac indistinct and vocal slits absent; tongue longer than wide, free behind; choanae relatively small, rounded; vomerine odontophores absent. Upper arm and forearm relatively slender, upper arm approximately as long as forearm; fingers I and IV absent; finger II distinct, short; finger III long, robust; tip of finger II nearly rounded, tip of finger III pointed; relative lengths of fingers II < III; no webs or disks on fingers or toes; subarticular tubercles and inner and outer metacarpal tubercles absent (Fig. $2 \mathrm{C}$ ). Legs relatively short, thigh robust; thigh length $50 \%$ of SVL, tibia length $88 \%$ of thigh length; toes I, II and V externally absent, toe III robust, short; toe IV robust, long; relative lengths of toes III < IV; subarticular tubercles and inner metatarsal tubercles absent; outer metatarsal tubercle vestigial (Fig. 2 D). Skin on top of the body surfaces smooth and with no dermal co-ossification (Fig. 1, 2 A). Measurements of holotype are in Table 1. 

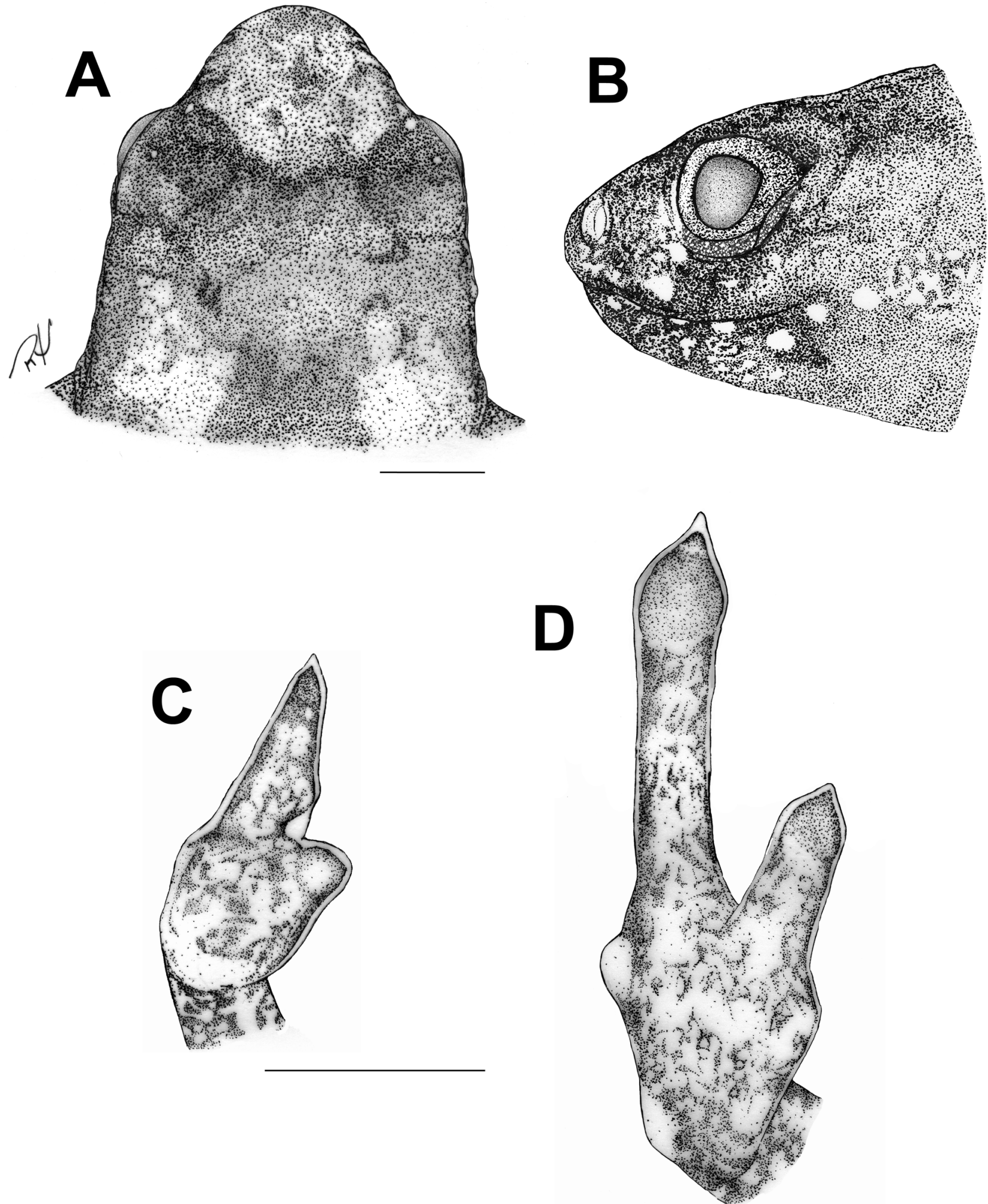

FIGURE 2. Holotype of Brachycephalus pulex sp. nov., MNRJ 69646, adult specimen. Dorsal (A) and lateral (B) views of head; ventral views of hand (C) and foot (D). Upper and lower horizontal lines equal $1.0 \mathrm{~mm}$.

Color of holotype. In preservative (70\% ethyl alcohol), dorsal surfaces light brown, darkened by numerous brown pin dots; eyeball blackish brown; dorsum maculated by dark brown marks: a thin and medially interrupted interorbital stripe, a x-shaped mark from posterior corners of eyes to sacral region, somewhat dimmed in its ends, and an inverted v-shaped mark from sacrum to vent, continuous with the $\mathrm{x}$-shaped mark. Forearms with scattered dark brown blotches somewhat anastomosed, absent on upper arms; outer edges of fingers II and III dark brown. 
Groin with a dark brown blotch, continuous with a dark brown diagonal transverse large stripe on thigh; knee dark brown; posterior surfaces of thighs with a continuous and curved dark brown stripe just below the vent; tibia with two dark brown stripes cranially, and a third one over the heel; foot with five small dark brown blotches from tarsus to fourth toe. Background color of ventral surfaces pale cream, darkened by numerous brown pin dots; chest with an inverted depigmented v-shaped mark bordered above by two dark brown stripes on each side; edges of throat and belly delimited by distinct depigmented circular areas, also scattered on the inferior surfaces of thighs and tarsus. Palm of hand and sole of foot widely depigmented.

TABLE 1. Descriptive statistics of adult specimens of the type-series of Brachycephalus pulex sp. nov., from the Serra Bonita mountain (type locality), Municipality of Camacan, State of Bahia, Brazil. M $\pm \mathrm{SD}$, arithmetic mean \pm standard deviation. Other abbreviations are defined in the text. Measurements are in millimeters.

\begin{tabular}{llllll}
\hline & $\begin{array}{l}\text { MNRJ 69646 } \\
\text { (holotype) }\end{array}$ & $\begin{array}{l}\text { MZUESC 8352 } \\
\text { (paratype) }\end{array}$ & $\begin{array}{l}\text { MZUESC 8604 } \\
\text { (paratype) }\end{array}$ & $\begin{array}{l}\text { MZUESC 8605 } \\
\text { (paratype) }\end{array}$ & M SD \\
\hline SVL & 8.2 & 8.1 & 8.4 & 8.0 & $8.2 \pm 0.1$ \\
HL & 3.1 & 3.1 & 3.5 & 3.3 & $3.3 \pm 0.2$ \\
HW & 3.3 & 3.4 & 3.0 & 3.3 & $3.3 \pm 0.2$ \\
ED & 1.3 & 1.1 & 1.1 & 1.1 & $1.2 \pm 0.1$ \\
END & 0.4 & 0.4 & 0.6 & 0.6 & $0.5 \pm 0.1$ \\
UEW & 0.8 & 0.8 & 0.7 & 0.6 & $0.7 \pm 0.1$ \\
IOD & 1.4 & 0.8 & 1.2 & 1.5 & $1.2 \pm 0.3$ \\
IND & 1.1 & 1.1 & 1.1 & 1.1 & $1.1 \pm 0.0$ \\
NSD & 0.8 & 0.8 & 0.8 & 0.9 & $0.8 \pm 0.0$ \\
THL & 4.1 & 3.9 & 4.2 & 4.1 & $4.1 \pm 0.1$ \\
TL & 3.6 & 3.3 & 3.5 & 3.3 & $3.4 \pm 0.1$ \\
FL & 5.5 & 5.0 & 5.5 & 5.5 & $5.4 \pm 0.2$ \\
\hline
\end{tabular}

Color in life. Description based in the paratype MZUESC 8604. Dorsal ground color maculated with variegated browns looking like dead leaves (Fig. 3). A dark brown $\mathrm{x}$-shaped mark is discernible over the dorsum, anastomosed caudally with a dark brown v-shaped mark over the sacrum, which in turn is continuous with dark brown stripes over the thighs, tibia and tarsus. Dorsal ground color surfaces anterior and posterior to the $\mathrm{x}$-shaped mark, reddish brown. Loreal region, flanks, concealed surfaces of thighs, and anterior surface of tibia, faded reddish brown. A light brown v-shaped interorbital area is delimited on the head cranially and caudally by two dark brown stripes, the former narrower than second. A dark brown mid-dorsal stripe extends perpendicularly from the cranial $\mathrm{v}$-shaped stripe to near the tip of snout, which in turn presents the same background color of the v-shaped interorbital area. Tarsus and posterior surface of tibia light brown. Ventral surfaces dark brown (Fig. 3), with an inverted blackish brown v-shaped mark on chest, and white blotches bordering the throat, belly, thighs, and tibia. An xshaped mark is outlined from the groin to the posterior undersurface of thighs by a row of white botches bordered externally by a blackish stripe. From the groin, these white blotches extend cranially to the posterior margins of chest, bordering the belly. Pupil black, iris orange.

Variation. Specimens are congruent with respect to the external morphologic characters and color pattern. Snout-vent lengths of juveniles are $5.5 \mathrm{~mm}$ (UFBA 10415) and $6.8 \mathrm{~mm}$ (UFBA 10416); sub-adult UFBA 10455 is $7.4 \mathrm{~mm}$. Measurements of adult paratopotypes are in Table 1.

Etymology. The specific name (pulex), a noun in apposition, refers to the flea, Pulex irritans, and is allusive to the small size and to the striking capacity for large leaps presented by the new species.

Geographic distribution and Natural History. Brachycephalus pulex is only known from the type locality, a forest remnant located in a mountain range regionally named Serra Bonita, with elevations ranging from 200 to 950 $\mathrm{m}$ above sea level, which leads to altitudinal changes in the vegetation, from evergreen forest with elements of moist lowland semi-deciduous forest, to moist submontane forest near the summits. The Serra Bonita mountain range lies in the municipalities of Camacan and Pau Brasil, in the State of Bahia, Brazil, and is one of the last remnants of moist submontane forest in the region. It covers an area of approximately 7,500 hectares, $130 \mathrm{~km}$ from the 
city of Ilhéus on the Atlantic coast and $526 \mathrm{~km}$ from the State capital of Salvador. Approximately $50 \%$ of the land cover is primary forest, and the remaining is a mosaic of forests in advanced stages of recuperation mixed with 'cabruca' (cocoa trees planted under natural forest canopy) and small areas of pasture. In the Serra Bonita there are several springs that provide fresh water for the inhabitants of Camacan and Pau Brasil. Brachycephalus pulex was captured within the Serra Bonita Reserve Complex (SBR), a Private Natural Heritage Reserve (RPPN), which comprises ca. 1,800 hectares of a "consortium" of privately owned properties (Instituto Uiraçu 2009). This is the first record of a Brachycephalus for the State of Bahia and the northernmost record for the coastal Atlantic Forest (but see below).
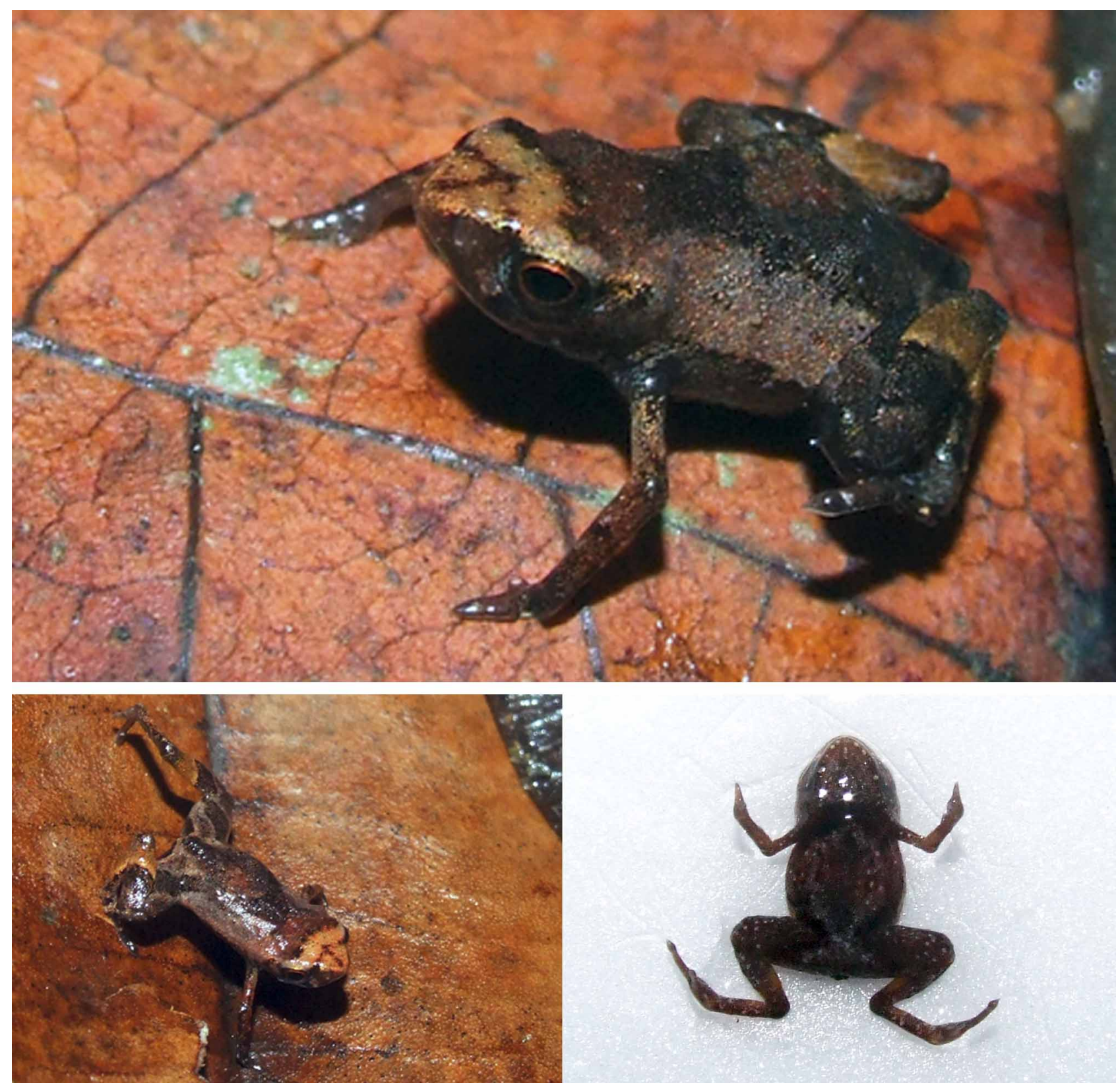

FIGURE 3. Living adult specimen of Brachycephalus pulex sp. nov., paratopotype, MZUESC 8604, from the Serra Bonita mountain, Municipality of Camacan, State of Bahia, Brazil; SVL 8.4 mm (Photos by Iuri R. Dias, 27 July 2010).

The new species was captured in a primary forest remnant provided with streams near the top of the mountain (800-930 m a.s.1.), within an area of dense leaf litter and several epiphytic bromeliads. At the time of specimens capture (December 2009 to July 2010), the minimum mean air temperature was $16.9^{\circ} \mathrm{C}\left(12-20{ }^{\circ} \mathrm{C}\right)$, the maximum $23.9^{\circ} \mathrm{C}\left(20-28{ }^{\circ} \mathrm{C}\right)$, and the average monthly precipitation was $188.6 \mathrm{~mm}(22.5-315 \mathrm{~mm})$. The specimens were captured beneath the leaf litter, except by one individual that was on a tree trunk $30 \mathrm{~cm}$ above the ground. One 
specimen when disturbed during the survey of anurans jumped away many times quickly and stopped over a dry leaf, remaining immovable (deaf feigning) even after we raise the leaf. This behavior was also observed for both juvenile paratypes. No vocalization was heard, although the advertisement call of the closely allied $B$. hermogenesi has been recorded and described by Verdade et al. (2008), and also for B. ephippium (Pombal et al. 1994).

Remarks. The northern geographic distribution limit of the genus Brachycephalus deserves some considerations. Hedges et al. (2008) stated that the genus Brachycephalus is restricted to the Atlantic Coastal Forest in the states of Rio de Janeiro, São Paulo, and Paraná in southeastern Brazil. In the same article, the authors provided a map with the geographic distribution of the genera Brachycephalus and Ischnocnema, in which the range distribution of the former extends to near the Brazilian State of Alagoas (ca. $10^{\circ} \mathrm{S}$ ). This mapped geographic distribution is contradictory to the information presented in the article itself and is not congruent with the literature, as the northernmost geographic distribution limit known for the genus Brachycephalus is that of B. alipioi in the municipalities of Vargem Alta, Forno Grande and Santa Teresa (ca. 20 S), all in the State of Espírito Santo, Brazil (Pombal \& Gasparini 2006), and that of B. ephippium in the Serra do Brigadeiro (ca. $20^{\circ} \mathrm{S}$ ) (Pombal 2001; Dayrell et al. 2006), a regional designation of the Serra da Mantiqueira mountain range in the State of Minas Gerais, Brazil. Dayrell et al. (2006) and Frost (2010) included in the geographic distribution range of B. ephippium the State of Bahia, Brazil. Indeed, the type locality of B. ephippium lies in the Municipality of Ilhéus, State of Bahia (Bokermann 1966), but Pombal et al. (1998) and Pombal and Gasparini (2006) already contested this information pointing out that possibly Spix's material was incorrectly labeled and the type locality is in error, as B. ephippium is common in the mountains of Rio de Janeiro city, where Spix also collected. In assuming this error in the label of Spix's material, Pombal and Gasparini (2006) considered B. alipioi as the northernmost species of the genus. Therefore, the presence of $B$. pulex in the Municipality of Camacan (ca. $15^{\circ} \mathrm{S}$ ), southern Bahia State, currently corresponds to the northernmost distribution limit of the genus Brachycephalus.

\section{Acknowledgements}

We are grateful to the Instituto Uiraçu, Vitor O. Becker and Clemira O. Souza for allowing us to access research areas under their care and for logistical assistance at the Serra Bonita; to Antônio J.S. Argôlo for allowing us to examine specimens under his care and for the donation to Museu Nacional of the specimen used as the holotype; to Angélica Y.C. Vargas, Rafael O. Abreu, Ariane L. Xavier, Jocilene B. Herrera, Maria S. Cunha, Emanuela Petersen, Euvaldo M.S.S. Junior, and Tadeu T. Medeiros for the field assistance; to Ivan Nunes and Rafael O. Abreu for color photographs of the holotype; to Rafael O. Abreu for line drawings. Part of the fieldworks was conducted during the discipline 'Métodos de Campo em Ecologia e Biomonitoramento' of the Postgraduate Program in Ecology and Biomonitoring of the Universidade Federal da Bahia, and part was made during the projects "Caracterização dos vertebrados terrestres do Complexo RPPN Serra Bonita como auxílio para sua gestão efetiva" supported by the Fundação O Boticário de Proteção à Natureza. The Instituto Brasileiro do Meio Ambiente e dos Recursos Naturais Renováveis (IBAMA) permitted collection of specimens (License numbers 12988-1 and 130012). The Conselho Nacional de Desenvolvimento Científico e Tecnológico (CNPq) awarded fellowships to Marcelo F. Napoli (Proc. 302542/2008-6), Ulisses Caramaschi (Proc. 307104/2006-0), and Carlos Alberto G. Cruz (Proc. 301172/2009-9). The Fundação de Amparo à Pesquisa do Estado da Bahia (FAPESB) for granting a Master's Scholarship to Iuri Ribeiro Dias.

\section{References}

Alves, A.C.R., Sawaya, R.J., Reis, S.F. \& Haddad, C.F.B. (2009) New species of Brachycephalus (Anura: Brachycephalidae) from the Atlantic Rain Forest in São Paulo State, southeastern Brazil. Journal of Herpetology, 43, 212-219.

Bokermann, W.C.A. (1966) Lista anotada das localidades tipo de anfíbios brasileiros. RUSP, São Paulo, 183 pp.

Dayrell, J.S., Oliveira, E.F., Cassini, C.S. \& Feio, R.N. (2006) Brachycephalus ephippium (Pumpkin Toadlet): geographic distribution. Herpetological Review, 37, 357.

Frost, D.R. (2010) Amphibian Species of the World: an Online Reference. Version 5.4 (08 April, 2010). Electronic Database available from http://research.amnh.org/vz/herpetology/amphibia/American Museum of Natural History, New York, USA (accessed 24 August 2010). 
Haddad, C.F.B, Alves, A.C.R., Clemente-Carvalho, R.B.G. \& Reis, S.F. (2010) A new species of Brachycephalus from the Atlantic Rain Forest in São Paulo State, southeastern Brazil (Amphibia: Anura: Brachycephalidae). Copeia, 2010(3), 410420.

Hedges, B., Duellman, W.E. \& Heinicke, M.P. (2008) New World direct-developing frogs (Anura: Terrarana): molecular phylogeny, classification, biogeography, and conservation. Zootaxa, 1737, 1-182.

Instituto Uiraçu (2009) Serra Bonita. Available from http://www.uiracu.org.br/serrabonita.html (accessed 14 December 2009 ).

Kaplan, K. (2002) Histology of the anteroventral part of the breastshoulder apparatus of Brachycephalus ephippium (Brachycephalidae) with comments on the validity of the genus Psyllophryne (Brachycephalidae). Amphibia-Reptilia, 23, $225-227$.

Napoli, M.F. (2005) A new species allied to Hyla circumdata (Anura: Hylidae) from Serra da Mantiqueira, Southeastern Brazil. Herpetologica, 61, 63-69.

Pombal, Jr., J.P. (2001) A new species of Brachycephalus (Anura: Brachycephalidae) from Atlantic Rain Forest of southeastern Brazil. Amphibia-Reptilia, 22, 179-185.

Pombal, Jr., J.P. (2010) A posição taxonômica das "variedades" de Brachycephalus ephippium (Spix, 1824) descritas por Miranda-Ribeiro, 1920 (Amphibia, Anura, Brachycephalidae). Boletim do Museu Nacional, Nova Série, Zoologia, 526, 112.

Pombal, Jr., J.P., Sazima, I. \& Haddad, C.F.B. (1994) Breeding behavior of the pumpkin toadlet, Brachycephalus ephippium (Brachycephalidae). Journal of Herpetology, 28, 516-519.

Pombal, Jr., J.P., Wistuba, E.M. \& Bornschein, M.R. (1998) A new species of Brachycephalid (Anura) from the Atlantic Rain Forest of Brazil. Journal of Herpetology, 32, 70-74.

Pombal, Jr., J.P. \& Gasparini, J.L. (2006) A new Brachycephalus (Anura: Brachycephalidae) from the Atlantic Rainforest of Espírito Santo, southeastern Brazil. South American Journal Herpetology, 1, 87-93.

Verdade, V.K., Rodrigues, M.T., Cassimiro, J., Pavan, D., Liou, N. \& Lange, M.C. (2008) Advertisement call, vocal activity, and geographic distribution of Brachycephalus hermogenesi (Giaretta \& Sawaya, 1998) (Anura, Brachycephalidae). Journal of Herpetology, 42, 542-549. 